\title{
VALUES DALAM DIPLOMASI EKONOMI CHINA
}

\author{
Linda \\ Chinese Department, Faculty of Language and Culture, Bina Nusantara University, \\ Jln. Kemanggisan Ilir III No. 45, Kemanggisan, Palmerah, Jakarta Barat 11480 \\ lianhua@binus.ac.id
}

\begin{abstract}
Rapid economic developments over the recent decades has made China to be the center of many researches. China has been known of having a unique technique of diplomacy. How a group of people interact with each other is strongly influenced by the values that has been developed in the social order. This paper uses research methods that focuses on literature reviews of books and articles that will explore the kind of values developed and is considered important and influential in the local society of China. This paper will also suggest techniques directly to China's economic diplomacy undertaken by both countries, individuals, or through joint venture.
\end{abstract}

Keywords: economic, diplomacy, values, China, negosiation, trading

\begin{abstract}
ABSTRAK
Perkembangan ekonomi yang luar biasa pesat selama beberapa dekade terakhir telah menjadikan China banyak dijadikan sentra penelitian. Pemantapan penggunaan soft power dalam diplomasi merupakan salah satu tools utama penetapan kebijakan luar negeri China dan China dikenal memiliki teknik diplomasi yang unik. Bagaimana sekelompok masyarakat berinteraksi satu dengan yang lainnya sangat dipengaruhi oleh values yang berkembang dalam tatanan masyarakat tersebut. Tulisan ini menggunakan metode penelitian yang berfokus pada tinjauan pustaka berupa buku dan artikel yang akan mengupas jenis-jenis values yang berkembang dan dianggap penting dan berpengaruh dalam masyarakat lokal China. Tulisan ini juga akan mengemukakan secara langsung teknik diplomasi ekonomi yang dilakukan China baik oleh negara, individu, maupun secara kongsi.
\end{abstract}

Kata kunci: ekonomi, diplomasi, value, China, negosiasi, perdagangan 


\section{PENDAHULUAN}

Dikenal luas sebagai negara berkembang yang tingkat pertumbuhannya paling mencengangkan selama tiga dekade terakhir, membuat pamor China di dunia internasional terus meningkat dari tahun ke tahun. Setelah bantuan yang begitu besar diberikan pada Asia untuk melewati Krisis Finansial pada tahun 1998, dengan berani China membeli obligasi Amerika Serikat untuk membantu perbaikan ekonomi negara adidaya tersebut setelah tertimpa Krisis Finansial Global pada pertengahan 2008. Hal ini menegaskan kedudukan China di dunia internasional.

Perkembangan ekonomi China yang begitu cepat dalam rentang waktu 30 tahun sering dituliskan para analis sebagai salah satu kisah sukses pembangunan ekonomi pada masa modern. Sejak tahun 1978 (ketika reformasi kebudayaan mulai dilakukan) hingga tahun 2008, GDP China rata-rata meningkat 10\% setiap tahunnya. Dari tahun 1980 hingga 2008, perekonomian China tumbuh 14 kali (Morrison, 2009). China kini merupakan negara dengan perekonomian terbesar kedua di dunia. Para peneliti bahkan memprediksi bahwa China akan menjadi yang terbesar dalam beberapa dekade mendatang.

Perdagangan dan investasi asing memainkan peranan yang sangat penting dalam pertumbuhan ekonomi negeri yang begitu signifikan. Ellen L. Frost dalam artikel "Promise or Threat? China's Commercial Diplomacy in Asia” mencatat di akhir tahun 1990, total Foreign Direct Investment (FDI) yang masuk ke China adalah yang ketiga terbesar dari total FDI di seluruh negara-negara berkembang. Tercatat sebesar 2,7 persen dari total 9,7 persen rata-rata GDP China berasal dari FDI. Pada tahun 2003, total FDI yang masuk ke China adalah sebesar US\$54 miliar, jauh mengungguli AS yang hanya mencatat sebesar US\$40 miliar. Sebanyak 23.500.000 lapangan pekerjaan tercipta dari sektor ini dan lebih dari 20,7 persen total pajak negeri berasal dari perusahaan investasi asing yang berada di China pada tahun 2005. Pada tahun 2004, total dari nilai perdagangan produk-produk China meningkat dua kali lipat. Hal ini, seperti dijelaskan oleh Morrison (2009), menjadikan China sebagai negara kedua eksportir terbesar dan importir ketiga terbesar di dunia. Lebih dari setengah volume perdagangan dilakukan oleh badan-badan investasi asing. Sepanjang tahun 2006 sendiri, sebanyak 594,445 perusahaan investasi asing terdaftar dengan lebih dari 480 perusahaan multinasional teratas dunia memasuki negara tersebut. Pada tahun 2008 total FDI yang masuk ke negara tersebut sebesar US\$ 92 millyar. China kini tercatat sebagai negara tujuan FDI terbesar ketiga di dunia.

Dengan mengombinasikan surplus perdagangan, aliran FDI dan pembelian ber-skala besar dari mata uang asing telah menjadikan China memegang pertukaran asing terbesar dengan total US\$ 1,9 billyar di akhir 2008. Secara lebih spesifik, China memproduksi 70 persen total mainan dunia dan 10 persen dari total peralatan telekomunikasi perusahaan dunia. Dan sekitar 60-70 persen dari total produksi di ekspor untuk kebutuhan asing. Meskipun krisis finansial global memberikan dampak yang cukup besar bagi perkembangan perekonomian, pada tahun 2009 pertumbuhan GDP negara China masih tercatat sebesar 8,9 persen pada kuartal ketiga, meningkat dari 7,9 persen pada kuartal kedua. Banyak peneliti juga meramalkan bahwa perekonomian akan mulai melambat atau bahkan menurun tajam pada tahun 2009. Jutaan pekerja telah dilaporkan kehilangan pekerjaan mereka dan hal ini merupakan titik utama perhatian pemerintah China yang melihat pertumbuhan ekonomi yang sehat merupakan hal yang sangat penting untuk menata stabilitas nasional.

Data-data di atas menyatakan besaran ekspansi yang dilakukan China. Di satu sisi China terus membutuhkan kucuran dana, di sisi lain terus berusaha memperluas pengaruhnya di dunia internasional dalam wujud menjadi negara investor atau negara pemberi bantuan. Satu catatan penting yang perlu digarisbawahi adalah cara yang digunakan China keseluruhannya tidak mengandalkan kekuatan militer (hard power), melainkan soft power. 
"Building a Harmonius World" adalah prinsip utama China dalam menetapkan kebijakan luar negeri, dan cara utama yang digunakan adalah diplomasi. Diplomasi yang digunakan-pun terbilang unik. Dengan berani China mendukung Iran dalam pengadaan pipa gas, kredit dan teknologi, sementara Amerika dan Eropa berupaya keras menekan pengembangan nuklir Iran. China juga membangun pipa gas dari teluk Bengal di Myanmar ke Propinsi Kunming di China, sementara pemerintah pusat di Beijing menolak bekerja sama dengan Amerika memerangi pencucian uang dan lalu lintas narkoba di Myanmar. Hal ini menjadikan posisi China sangat representatif sekaligus dilema. Di saat negara lain berbondong menyesuaikan diri dengan gaya negosiasi barat, dalam kasus China, justru orang-orang barat yang harus menyesuaikan diri dengan gaya negosiasi ala China.

Jumlah penduduk yang besar dan area wilayah yang sangat luas, menjadikan para investor harus ekstra hati-hati ketika bernegosiasi dengan China. Sistem negara yang dianut juga berbeda dari negara kebanyakan yang hanya menjalankan satu sistem saja (kapitalis atau sosialis). China memilih berjalan seimbang antara dua sistem, menyebutnya dengan kapitalis berkarakteristik China. Sulit memprediksi pola pikir yang sama di antara 1,4 milyar penduduk China dan sulit juga menerapkan sistem negosiasi yang sama di sejumlah kawasan investasi terbuka yang sama untuk setiap tempat di China. Menjadi penting bagi para investor atau negara-negara sumber pemberi FDI untuk mengetahui negara tujuan berinvestasi mereka atau dengan siapa sebenarnya mereka bekerja sama. Mengamati berbagai keunikan dan karakteristik yang dimiliki China saat ber-diplomasi atau ber-negosiasi di atas meja perundingan, penulis tertarik untuk menelaah karakteristik dasar masyarakat China yang mempengaruhi sikap dan pola pikir di atas meja perundingan. Values menjadi sorotan utama dalam makalah ini.

\section{PEMBAHASAN}

\section{Values dalam Kerangka Analisa Politik Luar Negeri}

David Easton menggambarkan politik dalam keadaan selalu bergejolak. Karena itu fokus perhatian Easton bersumber pada pertanyaan bagaimana mengelola sebuah sistem yang tetap utuh dalam situasi dunia yang penuh gejolak dan rentan pada perubahan. Sehingga, untuk menjawab pertanyaan ini, Easton meyakini pentingnya melakukan penelitian mengenai interaksi sistem politik dengan lingkungan, baik di dalam maupun di luar lingkup masyarakat. Secara sederhana, Easton mengungkapkan memahami sistem politik sama seperti memahami sistem lain seperti ekonomi, yang kesemuanya merupakan subsistem dari sistem yang lebih besar. Namun demikian, sistem politik menurut pandangan Easton bersifat khusus, karena memiliki kekuatan membuat keputusan yang mengikat semua anggota dalam sistem.

Easton memandang sistem politik sebagai tahapan pembuatan keputusan yang memiliki batasan dan sangat fleksibel (berubah sesuai kebutuhan). Model sistem politik terdiri dari fungsi input, berupa tuntutan dan dukungan; fungsi pengolahan (conversion); dan fungsi output sebagai hasil dari proses sistem politik, lebih jelasnya seperti pada Gambar 1 berikut:

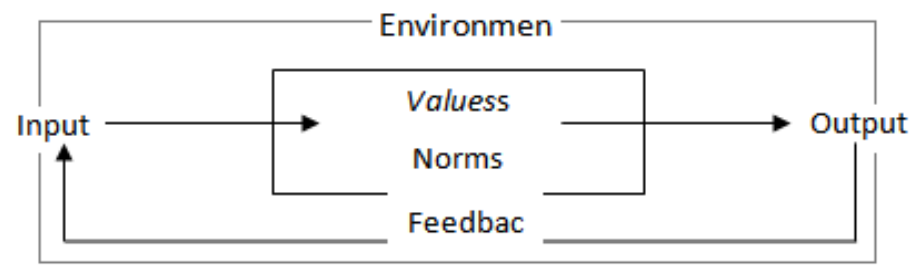

Gambar 1 Model Analisa Sistem Politik 
Ketika suatu sistem menerima sebuah input berupa kejadian atau fenomena yang terjadi di dunia masyarakat baik secara nasional maupun internasional, maka akan ada output berupa kebijakan. Ketika proses pengelolaan terjadi (conversion), ada beberapa faktor yang memainkan peranan penting, yaitu: environment (lingkungan) dan values (nilai). Environment merupakan faktor utama bagaimana sebuah input (kejadian bisa terjadi) dan proses pengelolaan kebijakan terjadi, lingkungan merupakan faktor penting yang harus diperhatikan. Howard Lentner mengungkap dua determinan pengambilan kebijakan luar negeri suatu negara, yaitu: domestik dan luar negeri. Hal-hal yang terjadi di dalam dan luar negeri memiliki pengaruh yang sangat besar pada kebijakan yang diambil. Namun, yang tidak kalah penting juga adalah Values (nilai).

Konsep values (nilai) yang berlaku dalam politik tidak setumpul nilai dalam ekonomi yang sering dimaknai sekedar efisiensi/laba. Dalam politik, values (nilai) bekerja berdasarkan norma-norma yang hidup dimasyarakat (Yustika, 2009). Values berasal dari norma yang dianut oleh suatu masyarakat, mengenai apa yang dianggap baik dan buruk oleh masyarakat. Drs. Suparto??? mengemukakan nilai-nilai sosial memiliki fungsi umum, diantaranya nilai-nilai yang dapat menyumbangkan seperangkat alat untuk mengarahkan masyarakat dalam berpikir dan bertingkah laku. Kimball Young mengemukakan nilai sosial adalah asumsi yang abstrak dan sering tidak disadari tentang apa yang dianggap penting dalam masyarakat. Values lahir dan berkembang dari hasil interaksi antar warga masyarakat dan dipengaruhi kebudayaan yang berkembang di suatu tempat serta mempengaruhi pengembangan diri sosial masyarakat tersebut.

Representasi dari values secara nyata adalah sikap dan perilaku masyarakat dari tempat dimana values tersebut berasal dan berkembang. Apa yang dipercaya oleh masyarakat setempat dan dijalankan oleh mereka, maka hal itulah yang disebut sebagai values. Sehingga dalam konteks Analisa Sistem Politik Luar negeri, dapat disimpulkan bahwa values suatu masyarakat atau disebut juga values sosial merupakan hal yang penting. Dan karena values berkembang di suatu tempat, maka values untuk setiap daerah dan wilayah dimuka bumi ini tidak dapat disamaratakan. Hal inilah yang menjadikan sebuah negara unik dan khas.

\section{Karakteristik Perilaku orang China}

China memiliki sejarah yang panjang dan budaya yang begitu besar. Penduduknya bangga dan lebih peduli pada sejarah masa lalu ketimbang barat. Ada banyak cerita dan legenda yang berkembang di China, kebanyakan berasal dari ratusan atau bahkan ribuan tahun yang lalu. Dan dari tiap-tiap cerita tersebut terdapat banyak pelajaran filosofi yang terkandung dari pemikir yang sudah dikenal baik oleh masyarakat. Berbicara mengenai perilaku dan sifat orang China, tidak dapat dilepaskan dari Konfusius. Konfusianisme adalah aliran pemikiran etika pertama yang menempatkan kepentingan bersama di atas kepentingan lainnya. Etika idealnya berpusat pada makna dasar kebaikan, berisikan bentuk-bentuk nilai moral utama, dengan bagian yang paling penting bakti pada orang tua dan tugas-tugas luhur, dan kesetiaan serta kebajikan.

Budaya China selalu memberikan tempat yang penting bagi kesalehan. Falsafah konfusius memegang teguh bahwa sebuah keluarga yang baik adalah suatu landasan yang baik bagi masyarakat yang baik dan keluarga yang baik didasarkan pada kasih orangtua kepada anaknya dan pengabdian dan ketaatan anak pada orangtuanya. Bakti pada orang tua bersama kesetiaan, ketaatan dan integritas membentuk moralitas yang berusaha ditanamkan dalam hati masyarakat oleh para pengikut Konfusius sepanjang sejarah bangsa China. Berbagai aliran filsafat terus berkembang selama sejarah panjang perkembangan masyarakat China. Dalam hal moralitas prinsip-prinsip dasar beberapa aliran pemikiran filsafat malah saling bertabrakan satu sama lain. Waktu telah menunjukkan bahwa beberapa falsafah hanya cocok untuk iklim politik di zamannya saja, berkembang dan kemudian lenyap dengan cepat. Falsafah yang tahan terhadap uji waktu akan terus bersinar sepanjang sejarah (Song Shouxiang, Profesor Chongqing Jianzhu University China, penulis "Loyalty, Kesetiaan”). Dari sinilah muncul nilai-nilai tradisional China yang kuat yang memiliki makna luas dalam masyarakat China. 
Integritas suatu pemerintahan, keteraturan dan harmoni sosial adalah faktor yang memiliki dampak langsung terhadap hukum dan moralitas masyarakat. Dengan mengembangkan nilai-nilai yang tetap dapat diterapkan dan membuang yang telah usang, ada makna baru yang diberikan pada nilai-nilai moral tradisional China. Dalam kondisi perekonomian modern saat ini, aturan moralitas ini masih dapat memberikan makna-makna praktis. Hal ini yang membedakan China dengan negaranegara lain. Penghargaan akan nilai-nilai sejarah dan budaya yang begitu kuat dan kental dapat dilihat langsung dari sikap dan perilaku sehari-hari. Sekalipun Mao Zedong secara keras mencoba menghapus pengaruh pemikiran Konfusius pada tahun 1960-an dan menggantikannya dengan ajaran Sosialis, namun hal tersebut hanya menjadi drama sejarah yang dramatis serta menjadi kritik bagi rezim tersebut selama bertahun-tahun.

Pengaruh Konfusius yang kuat inilah yang menjadikan Sosialis total yang ditetapkan oleh Mao Zedong berjalan timpang. Deng Xiaoping dengan semangat pembaruan, merombak sistem politik China menjadi lebih terbuka dan kapitalis. Perekonomian mulai tumbuh dengan cepat dan China mencoba merangkak kembali ke posisinya semula, menjadi sebuah negara yang selalu mereka sebut dengan 中国 (zhōngguó), sebuah negara sentral. Akan tetapi, meskipun sistem politik dan perekonomian berasal dari luar (Marxisme dan Liberalisme bukan ajaran yang berasal dari dalam negeri China), namun pada prakteknya, akar dari pemikiran, sikap dan perilaku para diplomat dan pebisnis China merupakan pencerminan dan representasi dari ajaran Konfusius.

Berikut beberapa karakteristik China yang berasal dari pemikiran Konfusius:

\section{关系(guānxì: Jaringan Hubungan)}

"Jangan selalu mengingat bantuan yang telah Anda berikan kepada orang lain, tetapi hendaknya jangan lupa untuk membalas budi yang telah Anda terima dari orang lain."

Guānxì secara harafiah dapat diartikan menjadi hubungan. Bagi orang-orang China tidak ada yang lebih penting daripada kedudukan seseorang dalam jaringan hubungan sosialnya. Awalnya, konsep penting guānxì berasal pada hubungan keluarga, tetapi gagasan ini telah melebar dan ikut mencakup teman, teman dari teman, mantan teman sekolah, relasi dan orangorang yang memiliki ketertarikan yang sama.

Media terciptanya guānxì adalah hubungan timbal balik. Hubungan ini dapat berupa pertolongan atau bantuan. Hubungan timbal balik jangka panjang ini bekerja baik dalam konteks hubungan pribadi jangka panjang. Di China, ketidakpedulian terhadap hubungan timbal balik ini adalah tata krama yang buruk; sesuatu yang tidak bermoral. Rekan bisnis potensial asal China harus didekati melalui jaringan mereka. Guānxì dapat menjadi sumber pengaruh yang penting selama berlangsungnya negosiasi. Referensi dari seorang anggota guānxì yang berpengaruh dapat memperkuat posisi dalam negosiasi ketimbang segudang informasi teknik yang akuran. Dengan pentingnya peran guānxì dalam budaya bisnis China, dapat dilihat bahwa sangat penting bagi para negosiator asing untuk membangun terlebih dahulu jaringan guānxì sebelum memulai negosiasi dengan para negosiator China.

\section{面子 (miànzi : gengsi)}

"Orang yang suka menjilat kepada orang kaya dan berkuasa adalah orang yang tercela."

Konsep mengenai miànzi di China sangat serupa dengan konsep kedaulatan dan gengsi di AS. Miànzi menentukan tempat seseorang dalam jaringan sosial. Ini adalah tolok-ukur nilai sosial yang paling penting. Miànzi dapat berupa kekayaan, kecerdasan, penampilan, keahlian, kedudukan dan guānxì yang hebat. 
Mengingkari janji, menunjukkan kemarahan, atau memperlihatkan perilaku yang tidak pantas dapat menyebabkan negosiator kehilangan muka/miànzi. Memberikan pujian dapat berarti menunjukkan pengakuan sosial terhadap lawan negosiasi, akan tetapi memuji berlebihan menandakan ketidaktulusan yang menyebabkan hilangnya miànzi.

Moral adalah landasan utama dari perilaku masyarakat China. Kesempurnaan moral manusia, baik sebagai seorang raja atau pekerja biasa, selalu menjadi perhatian utama. Inti dari moral adalah kebajikan (仁:ren). Pengertian ren yang diajukan oleh Konfusius adalah "cinta manusia”; yang berarti perbuatan baik anak pada orangtua, cinta kepada saudara dan kerabat, berbaik hati kepada orang tua, berbuat baik pada orang lain tanpa memandang status sosial dan hubungannya dengan diri seseorang. Dan kesemuanya ini menunjuk pada penghormatan diri sendiri. Memperlakukan orang lain dengan baik, berarti memperlakukan diri sendiri dengan baik. Menunjukkan penghormatan tinggi terhadap negosiator, berarti kita dapat menjaga kepercayaan yang diberikan yang bagi masyarakat China mutlak diperlukan.

\section{裙带关系 (qúndài guānxì : hubungan kekeluargaan)}

"Orang yang menilai uang lebih tinggi daripada orangtuanya adalah anak yang tidak berbudi."

Dalam struktur sosial masyarakat China, keluarga adalah yang terpenting. Keluarga menjadi unit sosial paling mendasar dan hal ini berlaku sejak dahulu hingga sekarang. Gordon Redding dalam Spirit of Chinese Capitalism mengatakan bahwa perusahaan yang dimiliki orang China jarang sekali berkembang melampaui ikatan dan batasan keluarga besar. Hal ini turut memberi warna dalam kapitalisme China, hal yang tidak dapat ditemui di Amerika Serikat, Jepang dan Eropa.

Penghargaan terhadap yang lebih tua atau bahkan leluhur yang sudah meninggal, merupakan warisan ajaran Konfusius yang masih melekat erat hingga sekarang. Hal ini menunjukkan penghargaan bangsa China yang tinggi terhadap sejarah dan ajaran-ajaran masa lalu.

Bagi masyarakat China, nepotisme merupakan lem yang menyatukan seluruh bagian organisasi. Bisnis keluarga sangat otokratis dimana sosok ayah biasa bertindak sebagai pemimpin. Uniknya, pertengkaran bisa saja pecah di ruang rapat keluarga, tetapi mereka akan selalu muncul dengan suara tunggal ketika menghadapi pihak luar. Kuatnya ikatan sosial dan kekeluargaan yang hidup dalam sistem bisnis China, merupakan salah satu karakteristik para negosiator China.

\section{社会等级 (shèhuì děngjí : hirarki sosial)}

"Dalam satu keluarga, orangtua dan anak-anak, suami dan istri, anak yang lebih tua dan anak yang lebih muda, harus mengerjakan tugas mereka masing-masing. Mereka semua harus mematuhi aturanaturan tingkah laku yang baik dan menggunakan bahasa yang pantas."

Ada lima jenis hubungan penting yang ditetapkan Konfusius; hubungan antara pemimpin dan yang dipimpin, suami dan istri, orang tua dan anak, kakak dan adik, dan pertemanan. Mereka yang dipimpin (istri, anak dan adik) disarankan untuk memberikan pengabdian dan kesetiaannya untuk mendapatkan kasih sayang dari pemimpinnya. Kepatuhan terhadap hubungan vertikal akan menghasilkan keharmonisan sosial.

Status bukan barang main-main, usia dan pangkat serta status adalah hal penting yang harus dipertimbangkan saat ber-negosiasi. Penghormatan terhadap yang lebih tua atau lebih tinggi status sosialnya dapat menjadikan hubungan yang harmonis, dan hubungan harmonis ini sangat penting bagi negosiasi. 


\title{
吃苦耐劳(chī kŭ nài láo : pantang menyerah dalam kepahitan dan penderitaan)
}

"Kita harus memperbaiki rumah sebelum hujan dan tidak terlambat menggali sumur saat kita sudah merasa haus."

Orang-orang China terkenal dengan etos kerjanya yang sangat tinggi. Kerja keras, bahkan di saat-saat tersulitpun adalah gagasannya. Kerja keras ini sudah dimulai sejak dini, di sekolahsekolah dengan jumlah jam belajar, jumlah hari sekolah dan masa sekolah yang jauh lebih panjang dari kebanyakan negara-negara lain, menjadikan kegigihan, kesungguhan dan persiapan sebagai ciri utama dari etos kerja orang China. Dan kembali, hal ini tidak dapat dilepaskan dari pengaruh Konfusius yang memang juga sudah sejak dini ditanamkan dalam pribadi masyarakat China.

\section{整体观念 (zhěngtǐ guānniàn: pandangan menyeluruh)}

"Apapun yang Anda lakukan, berusahalah meluangkan waktu untuk memikirkan kondisi-kondisi yang tak terduga. Jika Anda berhasil dalam suatu usaha, janganlah terlalu mengharapkan keberhasilan itu akan terulang kembali."

Salah satu ciri karakteristik lain yang istimewa adalah kemampuan untuk melihat gambaran besar. Sejak kecil anak-anak dididik mengenal huruf/karakter yang menyerupai simbol dan gambar. Karakter-karakter tersebut hanya dapat diartikan dengan melihat keseluruhan karakter, karena satu karakter bisa terdiri dari beberapa elemen yang baru lengkap dan memiliki arti jika kesemuanya digabungkan dan dilihat menjadi satu. Karena itu, orang-orang China cenderung membicarakan permasalahan sekaligus, berputar-putar di sekitar masalah utama. Dan ketika diimplementasikan di dalam bisnis, orang China lebih mampu menyelesaikan masalah secara globalgaris besar dan bukan rinci dan detail perbagian masalah seperti yang umum diterapkan para negosiator barat.

\section{令和谈判(ling hé tán pàn: kepercayaan dan perundingan) \\ "Orang yang berpengalaman, bertindak hati-hati, dan sederhana dapat diandalkan dalam kondisi sulit."}

Dalam budaya China, kerjasama dan saling percaya antar anggota keluarga adalah prosedur standar. Hubungan timbal balik dan negosiasi muncul dari saling ketergantungan yang telah tercipta. Akan tetapi, satu prinsip dasar dari negosiasi yang dipercayai oleh orang China adalah prinsip menang kalah dan hal ini dapat dilihat sebagai sebuah jenis peperangan. Bisnis dan ekonomi adalah medan peperangan masa kini. Tidak heran jika strategi perang yang ditulis oleh Sun Zi dapat diimplementasikan dalam dunia bisnis masa kini. Yang terpenting dari negosiasi adalah rasa saling percaya. Selalu sulit pada awalnya bagi orang dalam luar lingkaran hirarki China untuk dapat bernegosiasi. Akan tetapi, jika rasa saling percaya sudah tumbuh, maka pada saat itulah, jenis-jenis hubungan komersial terbaik dapat dinegosiasikan.

\begin{abstract}
Analisis
Dalam upaya memenuhi kepentingan nasional, kerjasama merupakan sebuah cara yang sangat diandalkan. Pertandingan pamor kekuatan militer sudah tidak dapat lagi dijadikan penentu sukses tidaknya sebuah entitas (Negara, Kelompok, MNC, NGO, Individu) memperoleh tujuan utamanya. Kerjasama adalah tekniknya, negosiasi adalah medianya dan diplomasi adalah alat penyampaian kepentingan dalam forum negosiasi. Menjadi penting untuk mengenali segala sesuatu mengenai lawan negosiasi, guna memperoleh komunikasi secara efektif. Menyesuaikan diri dengan kebiasaan lawan adalah cara terbaik menyesuaikan kepentingan kedua belah pihak.
\end{abstract}


Berbeda tempat dan lawan negosiasi, maka berbeda pula teknik diplomasi yang digunakan. China sebagai sebuah negara yang menjadi tempat investasi paling menjanjikan dewasa ini sangat memahami hal ini. Satu hal yang perlu dipahami adalah tingkat nasionalisme China yang begitu tinggi. Hal ini menjadikan penghargaan China pada leluhur dan warisan budaya serta sejarah masa lalu menjadi begitu kental dan kuat. Seperti yang telah dipaparkan pada bagian sebelumnya, bahwa yang menjadi kunci dari Values China selama beratus-ratus bahkan beribu tahun terakhir adalah kuatnya ajaran yang diterapkan oleh Konfusius. Ajaran-ajaran Konfusius berpengaruh dan melekat kuat pada pribadi, pola pikir, tingkah laku bahkan sikap dan sifat orang China. Sepanjang sejarah China, tercatat telah terjadi dua kali upaya penghapusan besar-besaran terhadap ajaran Konfusius. Yang pertama terjadi pada masa pemerintahan Kaisar I China, Qin Shihuang yang membunuh lebih dari 400 cendekiawan dan membumihanguskan semua kitab-kitab ajaran Konfusius. Pada masa ini, kitab terakhir Konfusius yaitu kitab musik hilang tidak berbekas hingga sekarang. Yang kedua terjadi pada masa revolusi kebudayaan yang di prakarsai oleh Mao Zedong pada tahun 1960an.

Ketika Republik Rakyat China (RRC) resmi didirikan Mao Zedong di lapangan Tiananmen, Beijing pada 1 Oktober 1949, sebagian besar rakyat China menyambut baik pemerintahan terpusat yang didasarkan pada ajaran sosialis. Ketika itu, pengaturan kolektif terhadap kehidupan di daerah perdesaan terus berlanjut. Hingga pada tahun 1957, terjadi pembersihan besar-besaran terhadap para penentang kebijakan Mao. Revolusi Kebudayaan yang dikomandoi Red Guard (Tentara bentukan Mao yang beranggotakan siswa sekolah menengah atas dan mahasiswa militan, untuk menjadi unit-unit paramiliter di seluruh penjuru negeri) ditugaskan untuk menyerang segala sesuatu yang bersifat tradisional. Berbagai situs dan peninggalan sejarah dihancurkan. Seluruh hal yang berhubungan dengan penentangan ajaran Mao termasuk para pengikut Konfusius dibumihanguskan.

Akan tetapi, semua hal ini tidak terlalu memberi pengaruh besar terhadap dasar values China. Nilai-nilai ajaran Konfusius tetap menjadi landasan dan acuan utama bagi kebanyakan warga China dalam bersikap, bertindak dan berperilaku. Sebagai contoh, ketika Komunis pertama kali mengambil alih China Daratan, salah satu tindakan pertama adalah memberikan status hukum yang sama antara wanita dengan pria. Secara resmi, para wanita mendapatkan gaji dan status yang sama dalam dunia kerja. Wanita memegang posisi penting di pabrik, kantor, kementrian dan angkatan bersenjata. Namun, ajaran Konfusius yang masih memegang teguh posisi lelaki di atas posisi wanita masih tetap hidup. Hal ini dapat dilihat dari timpangnya statistik populasi pria dibandingkan wanita. Dimana jumlah para pria jauh melebihi wanita. Dalam hal ini dapat dilihat bahwa pengaruh values yang berasal dari dalam negeri (Konfusius) jauh lebih kuat dibandingkan yang berasal dari luar negeri (Marxisme).

Hal lain yang dapat dilihat sekaitan kuatnya pengaruh ajaran Konfusius dalam tatanan kehidupan sosial masyarakat China adalah eratnya hubungan kekeluargaan di dalam tata kelola bisnis China. Kesetaraan sosial yang dilakukan pihak komunis telah mengurangi pentingnya arti hubungan kekeluargaan (qúndài guānxi) di China. Karena sebagian besar kekayan dan sumber daya di China dikuasai partai Komunis sejak tahun 1949, maka sistem pemerintahanpun berubah. Banyak anggota partai yang berkuasa (di China, masih disahkan sistem posisi ganda, dimana seseorang yang memiliki kedudukan di partai juga dapat memegang posisi penting di militer atau perusahaan negara), sebagian kecil elit pemerintahan, mahasiswa-mahasiswa universitas ternama seperti Qinghua University dan Beijing University, sering kali menempati posisi yang lebih penting ketimbang hubungan keluarga. Namun, hal ini hanya terjadi di dalam negara saja. Pada saat yang bersamaan, di Hongkong, Singapura, Taiwan, Amerika Serikat bahkan Eropa, konsep penting dari hubungan kekeluargaan (qúndài guānxì) masih terus melekat kuat pada para perantau asal negeri tirai bambu tersebut. Dan seiring dengan semakin pudarnya pamor komunis di China daratan dan kembali terbukanya China dengan dunia luar, pada akhirnya konsep penting hubungan kekeluargaan (qúndài guānxì) kembali menemukan posisinya. Sekali lagi, hal ini membuktikan bahwa sekalipun China telah menjalankan sebuah sistem yang berasal dari pengaruh asing (Marxisme), kekuatan dan kearifan budaya lokal tetap mengakar kuat dalam tatanan kehidupan sosial masyarakat China. 
Beberapa contoh di atas, memperlihatkan meskipun komunisme telah mengakibatkan kehancuran sistem sosial masyarakat, namun dasar dari Konfusianisme terus melekat dan dipraktekkan erat dalam berbagai elemen Kebijakan Luar Negeri. Penulis berpendapat, salah satu representasi kuat dari ajaran Konfusianisme dalam Kebijakan Luar Negeri China adalah dengan sikapnya untuk tidak mencampuri urusan politik dalam negeri negara lain. Kepentingan China di negara tersebut adalah untuk bekerja sama dalam bidang ekonomi dan hal ini tidak ada kaitannya sama sekali dengan domestik negara tersebut. Contoh nyata yang dapat dilihat adalah pada kasus Iran. Bagi penulis, dengan jelas sekali China tidak terganggu dengan keadaan politik dalam negeri Iran. Dengan berani, China mendukung Iran dalam pengadaan pipa gas, kredit dan teknologi, sementara Amerika dan beberapa negara Eropa lain sibuk menekan upaya pengembangan nuklir Iran. Hal ini mendapat sambutan positif dan penghargaan tersendiri dari Iran dan negara-negara lain yang memiliki kasus serupa Iran terhadap posisi China. Penghargaan ini menjadikan China kuat di mata negara-negara Asia dan Afrika yang mendatangkan dukungan kuat bagi tindakan-tindakan China di dunia Internasional. Konsep penting dari miànzi dengan jelas tergambar. Bantuan yang diberikan tidak diharapkan balasannya pada saat itu, akan tetapi pasti ada suatu masa dimana China membutuhkan bantuan dari negara lain. Dan hal ini kembali terbukti pada kasus Hak Asasi Manusia di Tibet. Banyak negara yang mendukung China dan menganggap kasus tersebut adalah masalah domestik pemerintah China, sehingga tidak perlu diganggu gugat.

Data-data dan contoh-contoh diatas, membawa kita untuk melihat sebuah kondisi dimana pentingnya peran values dalam sikap dan perilaku sebuah bangsa dalam menghadapi fenomena dunia internasional yang terjadi. Beragam keputusan dan tindakan China di dunia internasional, tidak dapat dipisahkan dari pengaruh ajaran Konfusius yang sudah terlanjur merekat kuat pada setiap pribadi orang China. Jika dilihat dari bagan analisa sistem politik yang dikembangkan oleh David Easton, maka dapat dilihat ada tiga fase penting dari sistem politik, yaitu input, pengolahan (conversion); dan fungsi output sebagai hasil dari proses sistem politik. Input dapat berarti sama bagi setiap negara di dunia.

Contoh kasus untuk model ini adalah Myanmar. Kejadian/inputnya adalah praktek pencucian uang dan lalu lintas narkoba yang sangat marak di Myanmar. Ketika hal ini terjadi, maka proses selanjutnya yang terjadi adalah proses konversi/pengolahan. Pada proses ini values, lingkungan dan kepentingan negara bermain. Jika pada Amerika memiliki karakteristik pendekatan tersusun secara berurut dalam memecahkan masalah, memecah rangkaian masalah kompleks menjadi lebih kecil dan menyelesaikannya satu demi satu seperti dalam wujud kecaman, embargo atau bahkan tindakan invasi militer. Maka China lebih melihat gambaran luasnya, memetakan apa kepentingannya di Myanmar dan bagaimana cara menyelesaikan masalah tanpa mengganggu kepentingannya. Karena itu, China lebih memilih untuk tidak bekerjasama dengan Amerika dalam mengatasi kasus Myanmar. Proses pengolahan ini adalah yang terpenting dari sebuah sistem politik dimana sebuah kasus yang sama dapat menghasilkan penyelesaian yang berbeda-beda. Hal ini menjadikan diplomasi ekonomi China berbeda. Berbagai literatur menyebutkan bahwa Amerika Serikat sendiri mengalami kesulitan ketika harus mengadakan negosiasi dengan para negosiator China. Perbedaan budaya dan values adalah dasarnya. Dan penting bagi para negosiator untuk memahami budaya dan values yang berkembang di tempat dimana investasi atau jalinan kerjasama akan dilakukan.

\section{PENUTUP}

Sepak terjang sebuah negara dalam dunia internasional tidak terlepas dari strategi dan sistem politik yang ditetapkan oleh pemerintah negaranya. Satu hal yang sangat berpengaruh bagi hubungan luar negeri antar negara adalah values yang tertanam dan berpengaruh dalam kehidupan masyarakat negara tersebut. Values dalam sistem masyarakat China sangat berbeda dan unik, sehingga terkadang menimbulkan kesulitan bagi para diplomat asing atau pelaku bisnis dalam berbuhungan dengan China. 
Menjadi penting untuk mengetahui dan memahami sistem values dalam tatanan masyarakat China dan Konfusius sebagai sebuah ajaran yang telah berkembang di China sejak lima ribu tahun yang lalu tetap menjadi akar values masyarakat China. Karena itu, untuk dapat lebih memahami teknik diplomasi yang digunakan baik pada level negara China, individu, maupun kongsi maka mempelajari dan memahami apa dan bagaimana values bahkan ajaran Konfusius terlebih dahulu merupakan cara yang sangat disarankan.

\section{DAFTAR PUSTAKA}

Morrison, W. M. (2009, Maret 9). China Economic Condition. CRS Report for Congress.

Yustika, A. E. (2009). Ekonomi Politik, Kajian Teoretis dan Analisis Empiris. Jogjakarta: Pustaka Pelajar. 